\title{
PENINGKATAN AKTIVITAS BELAJAR DAN HASIL BELAJAR QUR'AN HADITS MELALUI PEMBELAJARAN INTERPRETATIF BERBASIS ICT
}

\author{
DIANAH \\ MTs. NU Banat Kudus \\ e-mail : dianahkudus@gmail.com
}

\begin{abstract}
ABSTRAK
Penelitian ini bertujuan untuk: (1) Meningkatkan aktivitas belajar siswa dengan pembelajaran yang berbasis ICT pada pembelajaran Qur'an Hadits pada siswa kelas IX A MTs NU Banat Kudus. (2) Meningkatkan hasil belajar Qur'an Hadits pada materi hukum bacaan mad lazim mukhaffaf kilmi, mad lazim mutsaqqal kilmi, mad lazim mukhaffaf harfi dan mad lazim mutsaqqal harfi melalui pembelajaran interpretatif berbasis ICT siswa kelas IX A MTs NU Banat Kudus. Untuk membantu siswa dalam meningkatkan hasil belajar, sehingga tujuan pembelajaran dapat tercapai, maka diperlukan alat media yang salah satunya adalah penggunaan media ICT dalam pembelajaran. Subyek penelitian adalah siswa kelas IX A MTs NU Banat Kudustahun pelajaran 2019/2020sejumlah 42 siswa. Prosedur penelitian meliputi 3 tahap, yaitu: tahap persiapan (mendesain pembelajaran), tahap pelaksanaan (Pre-test, Siklus I, dan Siklus II) dan tahap penyusunan laporan. Pelaksanaan Siklus I dan II, meliputi: perencanaan, pelaksanaan tindakan (kegiatan guru dan siswa), observasi dan reflleksi.Ketuntasan belajar siswa (yang mendapat nilai KKM ke atas atau yang memperoleh 77 ke atas yaitu dari 20 siswa (47,62 \%) sebelum tindakan, menjadi 28 siswa $(66,67 \%)$ setelah Siklus I dan mengalami peningkatan menjadi 37 siswa atau $(85,71 \%)$ setelah Siklus II. Interaksi siswa dalam diskusi kelompok juga mengalami peningkatan dengan kategori terbaik pada Siklus I sebanyak 11,1 \% pada Siklus II mengalami peningkatan menjadi 55,6\%, kategori baik pada Siklus I sebanyak 22,2 \% pada Siklus II naik menjadi 33,3\%, kategori cukup baik pada Siklus I sebanyak 44,5\% pada Siklus II berkurang menjadi $11,1 \%$, dan pada Siklus I untuk kategori kurang baik sebanyak $22,2 \%$ pada Siklus II tidak ada (0 \%). Berdasarkan hasil analisis aktivitas siswa dalam kelompoknya serta hasil belajar siswa dalam pemberian tindakan dengan menggunakan pembelajaran berbasis ICT diperioleh peningkatan baik aktivitas siswa dalam kelompok maupun hasil belajar siswa, sehingga dapat disimpulkan bahwa pembelajaran berbasis ICT mampu meningkatkan aktivitas maupun hasil belajar siswa MTs NU Banat Kudus.

Kata Kunci : Aktivitas belajar, hasil belajar, dan interpretatif berbasis ICT
\end{abstract}

\section{ABSTRACT}

This study aims to: (1) Increase student learning activities with ICT-based learning in Qur'an Hadith learning in class IX A MTs NU Banat Kudus. (2) Improving the learning outcomes of the Qur'an Hadith on legal material reading Mad Common Mukhaffaf kilmi, Mad Common Mutsaqqal Kilmi, Mad Common Mukhaffaf Harfi and Mad Common Mutsaqqal Harfi through ICT-based interpretive learning for class IX A MTs NU Banat Kudus. To assist students in improving learning outcomes, so that learning objectives can be achieved, media tools are needed, one of which is the use of ICT media in learning. The research subjects were students of class IX A MTs NU Banat Kudus in the 2019/2020 school year totaling 42 students. The research procedure includes 3 stages, namely: the preparation stage (learning design), the implementation stage (Pre-test, Cycle I, and Cycle II) and the stage of preparing reports. The implementation of Cycles I and II, includes: planning, implementing actions (teacher and student activities), observation and reflection. Completeness of student learning (those who get the KKM score and above or who get 77 and above that is from 20 students (47.62\%) before action, became 28 students (66.67\%) after Cycle I and increased to 37 students or $(85.71 \%)$ after Cycle II. Student interaction in group discussions also increased with the best category in Cycle I as much as $11.1 \%$ in Cycle II it increased to 55.6\%, good category in Cycle I was 22.2\% in Cycle II it rose to $33.3 \%$, good enough category in Cycle I was $44.5 \%$ in Cycle II it was 
reduced to $11.1 \%$, and in Cycle I for the unfavorable category as much as $22.2 \%$ in Cycle II there is no $(0 \%)$. both student activity in groups and student learning outcomes, so it can be concluded that ICT-based learning is able to increase student activity and learning outcomes at MTs NU Banat Kudus.

Keywords: Learning activities, learning outcomes, and ICT-based interpretive

\section{PENDAHULUAN}

Pelaksanaan pengajaran merupakan proses kegiatan mengajar untuk menyampaikan seperangkat ilmu pengetahuan kepada siswa. Oleh karena itu, seorang guru harus mengikuti perkembangan ilmu pengetahuan dan teknologi yang sangat pesat. Keberadaan siswa tidak lepas sebagai salah satu objek dasar dalam pelaksanaan proses belajar mengajar.Perkembangan teknologi yang sangat pesat ini, harus selaras dengan peningkatan mutu SDM (Sumber Daya Manusia) arah perkembangan ilmu pengetahuan dan teknologi dapat menuju sasaran yang tepat. Sebagai guru, perhatian harus seksama dalam peningkatan mutu SDM, khususnya dalam melihat permasalahan-permasalahan dan perkembangan di dalam proses pembelajaran, serta siswa maupun bahan ajar yang kami ajarkan.

Qur'an Hadis adalah bagian dari mata pelajaran pendidikan agama islam yang diberikan untuk memahami dan mengamalkan Al-Qur'an sehingga mampu membaca dengan fasih, menerjemahkan, menyimpulkan isi kandungan, menyalin dan menghafal ayat-ayat yang terpilih serta memahami dan mengamalkan hadis-hadis pilihan sebagai pendalaman dan perluasan kajian dari pelajaran Al-Qur'an Hadis dan sebagai bekal untuk mengikuti jenjang pendidikan berikutnya.Mempelajari Qur' an Hadis bertujuan agar peserta didik gemar membaca Al-Qur'an dan Hadis dengan benar, serta mempelajarinya, memahami, meyakini kebenarannya, dan mengamalkan ajaran-ajaran yang terkandung didalamnya sebagai petunjuk dan pedoman dalam seluruh aspek kehidupan. Dengan demikianpembelajaran Al-Qur'an Hadis memiiki fungsi lebih istimewa dibanding dengan yang lain dalam hal mempelajari Al-Qur'an.

Pembelajaran Qur'an Hadits di MTs NU Banat Kudus, aktivitas dan hasil belajarnya masih rendah, ini ditandai minat dan semangat belajar yang kendor, kemampuan dalam proses memahami juga rendah, kemampuan menganalisis soal sangat terbatas dan kemampuan dalam pencapaian KKM (Kriteria Ketuntasan Minimal) masih dibawah standar, secara umum aktivitas dan hasil belajar dianggap masih dibawah rata-rata. Di sisi lain tinjauan terhadap guru sendiri biasanya ada materi yang susah diajarkan artinya disamping materinya agak susah juga media pembelajaran yang kurang memadai misalnya pada materi hukum bacaan mad. Pada materi ini dalam RPP (Rencana Pelaksanaan Pembelajaran) tertera 2 X 2 pertemuan, akan tetapi karena materi agak susah dimengerti siswa maka pertemuan ditambah menjadi 5 atau 6 kali, itupun perolehan yang dicapai belum optimal. Di samping itu juga dalam silabus materi Qur'an Hadits pada umumnya masihdi anggap sangat padat, sementara jumlah pertemuan sangat terbatas.

Berdasarkan pengalaman guru dalam mengajar, ternyata dari hasil ulangan Qur'an Hadits cenderung siswa memperoleh hasil atau nilai yang masih rendah. Sebagai guru di kelas IX selalu merasa kurang puas dengan hasil belajar siswa tersebut, dari setiap hasil ulangan sebagian besar siswa cenderung belum mencapaiKKM yang telah ditetapkan sebesar 77 (tujuh puluh tujuh). Baru setelah diadakan ulangan perbaikan, ketuntasan klasikal tercapai, dan itupun mesti dilakukan berulang kali, bahkan pada beberapa materi yang dianggap lebih sulit diberikan ulangan perbaikan (remedial).

Sesuai dengan alokasi dalam kurikulum dan pembagian jam pembelajaran yang diberlakukan sekarang, sangat tidak memungkinkan untuk memberikan ulangan perbaikan berkali-kali pada jam-jam pembelajaran efektif di pagi hari, karena hal ini akan menghambat materi-materi pelajaran berikutnya, sehingga penulis merasa perlu mencari solusi yang terbaik untuk mengatasi permasalahan di atas.Menurut Montessori dalam Hamalik (2006:171) pengajaran yang efektif adalah pengajaran yang menyediakan kesempatan belajar sendiri atau melakukan aktivitas sendiri. Anak ( siswa) belajar sambil bekerja. Dengan bekerja mereka memperoleh pengetahuan, pemahaman, dan aspek-aspek tingkah laku lainnya. Serta mengembangkan keterampilan yang bermakna untuk hidup dimasyarakat. Dalam kemajuan metodologi dewasa ini asas aktivitas lebih ditonjolkan 
melalui suatu program unit activity, sehingga kegiatan belajar siswa menjadi dasar untuk mencapai tujuan dan hasil belajar yang lebih memadai.

Fakta hasil ulangan pada materi hukum bacaan mad lazim mukhaffaf kilmi, mad lazim mutsaqqal kilmi, mad lazim mukhaffaf harfi dan mad lazim mutsaqqal harfi diperoleh hasil bahwa hanya 20 siswa atau 47,62 \% dari 42 siswa di kelas IX A MTs NU Banat Kudus yang dinyatakan mencapai ketuntasan belajar secara klasikal atau yang mendapat nilai KKM atau 77, sedangkan sisanya 22 siswa atau 52,38 \% masih belum mencapai KKM. Hal ini diduga disebabkan oleh beberapa faktor antara lain kurangnya motivasi belajar dan semangat untuk memahami mata pelajaran Qur'an Hadits.

Menurut Slameto (2007:89) untukmemperoleh hasil belajar yang tinggi sebenarnya banyak faktor yang mempengaruhi. Faktor-faktor yang mempengaruhi prestasi hasil belajar meliputi (1) faktor siswa; (2) faktor pengajar (guru); (3) bahan dan materi yang dipelajari; (4) media pengajaran; (5) karakteristik fisik sekolah; (6) faktor lingkungan dan situasi. Karakteristik siswa meliputi karakteristik psikis yang terdiri dari kemampuan intelektual dan kemampuan non intelektual seperti sikap dan kebiasaan belajar, minat, perhatian, bakat, motivasi dan kondisi psikis seperti pengamatan, fantasi, persepsi, dan perasaan.

Permasalahan yang ada disikapi dengan memberikan rangsangan dengan penerapan penggunaan media pembelajaran yang berbasis ICT (Information and Communication Technology), karena dengan memberikan media pembelajaran berupa ICT maka siswa akan termotivasi, tertantang, menyenangkan, terinspirasi dan interaktif, karena menurut Sumiati (2008:164) manfaat media pembelajaran mampu untuk mengatasi keterbatasan ruang, waktu dan indera.Penerapan metode dengan pemakaian media ICT dapat meningkatkan minat, kemampuan, dan pembelajaran menjadi I2M3( interaktif, inspiratif, menyenangkan, memotivasi dan menantang). Menurut Usman (2006:32) nilai dan manfaat media mendorong anak untuk bertanya dan berdiskusi karena ia ingin lebih banyak perkataan, tetapi juga memperlihatkan suatu gambar benda yang sebenarnya atau alat lain.Berdasarkan PP No.19 Tahun 2005 pasal 19, ayat 1yang berbunyi.Proses Pembelajaran pada satuan pendidikan diselenggarakan secara interaktif, inspiratif, menyenangkan, menantang, memotivasi, peserta didik untuk berpartisipasi aktif, serta memberikan ruang yang cukup bagi prakarsa, kreativitas, sesuai dengan bakat, minat, dan perkembangan fisik serta psikologis peserta didik.

Oleh karena itu,peneliti melakukan Penelitian Tindakan Kelas (PTK) dengan judul, “Peningkatan Aktivitas Belajar dan Hasil Belajar Qur'an Hadits pada Pada Materi hukum bacaan mad lazim mukhaffaf kilmi, Mad Lazim Mutsaqqal Kilmi, Mad Lazim Mukhaffaf Harfi dan Mad Lazim Mutsaqqal Harfi melalui Pembelajaran Interpretatif Berbasis ICT Siswa Kelas MTs IX A MTs NU Banat Kudus Tahun Pelajaran 2019/2020”.

\section{METODE PENELITIAN}

Model penelitian ini adalah penelitian tindakan kelas (class roomaction research). Metode yang dipakai oleh peneliti untuk mendapatkan informasi adalah dokumentasi yang digunakan untuk mengetahui dan mendapatkan daftar nama peserta didik yang menjadi sampel penelitian yaitu Classroom Action Research, metode pengamatan (observasi) digunakan untuk mendapatkan data tentang keaktifan siswa kelas IX A MTs NU Banat Kudus setelah melakukan model pembelajaran interpretatif berbasis ICT pada pembelajaran Qur'an Hadits materi hadits tentang ketentuan hukum bacaan mad lazim mukhaffaf kilmi, mad lazim mutsaqqal kilmi, mad lazim mukhaffaf harfi, dan mad lazim mutsaqqal harfi, Tes digunakan untuk mendapatkan data prestasi belajar siswa kelas IX A MTs NU Banat Kudus setelah melakukan model pembelajaran interpretatif berbasis ICT pada pembelajaran Qur'an Hadits sebagai evaluasi setelah proses pembelajaran berlangsung. Subyek dalam penelitian ini adalah siswa kelas IX MTs NU Banat Kudus tahun pelajaran 2019/2020, sedangkan sampel penelitian diambil dari kelas IX A karena hasil belajar dan kerjasama antar siswa pada pembelajaran kompetensi sebelumnya masih rendah dan jumlah siswa kelas IX A ada 42 orang. Dengan langkah-langkah pra siklus dan 2 siklus, dan setiap siklusnya melalui tahapan-tahapan perencanaan, pelaksanaan, pengamatan dan refleksi. Análisis yang digunakan adalah análisis kualitatif digunakan untuk 
menggambarkan keberhasilan pembelajaran interpretatif berbasis ICT dalam pembelajaran materi Qur'an Hadits tentang tentang ketentuan hukum bacaan mad lazim mukhaffaf kilmi, mad lazim mutsaqqal kilmi, mad lazim mukhaffaf harfi, dan mad lazim mutsaqqal harfi di kelas IX A MTs NU Banat Kudus dengan melihat tanda-tanda perubahan pada siswa dalam proses pembelajaran. Dan análisis kuantitatif digunakan untuk menganalisis jumlah siswa yang mengalami peningkatan hasil belajar dalam pembelajaran materi Qur'an Hadits tentang tentang ketentuan hukum bacaan mad lazim mukhaffaf kilmi, mad lazim mutsaqqal kilmi, mad lazim mukhaffaf harfi, dan mad lazim mutsaqqal harfi di kelas IX A MTs NU Banat Kudus yang diperoleh dari tindakan siklus I dan II.

\section{HASIL DAN PEMBAHASAN}

\section{A. Kondisi Awal}

Pembelajaran Qur'an Hadits di MTs NU Banat Kudus, aktivitas dan hasil belajarnya masih rendah, ini ditandai minat dan semangat belajar yang kendor, kemampuan dalam proses mengidentifikasi juga rendah, kemampuan menganalisis soal sangat terbatas dan kemampuan dalam pencapaian KKM (Kriteria Ketuntasan Minimal) masih dibawah standar, secara umum aktivitas dan hasil belajar dianggap masih dibawah rata-rata. Di sisi lain tinjauan terhadap guru sendiri biasanya ada materi yang susah diajarkan artinya disamping materinya agak susah juga media pembelajaran yang kurang memadai misalnya pada materi hukum bacaan mad. Di samping itu juga dalam silabus materi Qur'an Hadits pada umumnya masihdi anggap sangat padat, sementara jumlah pertemuan sangat terbatas.

Permasalahan yang ada disikapi dengan memberikan rangsangan dengan penerapan penggunaan media pembelajaran yang berbasis ICT (Information and Communication Technology), karena dengan memberikan media pembelajaran berupa ICT maka siswa akan termotivasi, tertantang, menyenankan, terinspirasi dan interaktif, karena menurut Sumiati (2008:164) manfaat media pembelajaran mampu untuk mengatasi keterbatasan ruang, waktu dan indera.

Hasil ulangan harian (formatif) pada tes kompetensi dasar sebelumnya (sebelum tindakan) diperoleh hasil yang masih rendah, yaitu hanya 47,62 \% atau 20 siswa dari 42 siswa yang memperoleh nilai secara klasikal di atas Kriteria Ketuntasan Minimal (KKM) dengan batas nilai 77. Hal ini disebabkan karena aktivitas dan belajar siswa yang masih rendah, cara pembelajaran yang masih terfokus pada guru, dan rasa canggung untuk bertanya guru, serta belum terbiasa dengan belajar diskusi kelompok. Selain itu juga karena siswa merasa kesulitan dengan menghafal banyak ayat al-Qur'an. Pada hal belajar Qur'an Hadits tidak semestinya hanya membaca dan menghafal ayat-ayat saja, tetapi juga lebih ditekankan pada pemahaman tentang cara membaca Al-Qur'an yang benar.

Supaya siswa tidak merasa sulit belajar Qur'an Hadits dan tidak canggung bertanya, sebagai upaya meningkatkan aktivitas belajar yang akhirnya akan meningkatkan hasil belajar siswa, serta membiasakan interaksi dalam diskusi kelompok maka dengan menerapkan penggunaan media ICT dalam pembelajaran dan diskusi kelompok diharapkan semua hal di atas dapat teratasi, karena metode ini lebih menekankan pada peningkatan aktivitas siswa dan interaksi siswa dalam diskusi kelompok. 


\section{B. Siklus I}

Distribusi dan kategori nilai siklus I dapat dilihat pada tabel berikut:

Tabel 1. Distribusi dan Kategori Nilai Siklus I

\begin{tabular}{|c|c|c|c|c|}
\hline No. & Interval Nilai & Jumlah Siswa & Prosentase $(\%)$ & Kategori \\
\hline $\begin{array}{l}1 . \\
2 . \\
3 . \\
4 .\end{array}$ & $\begin{array}{c}\geq 90 \\
80-89 \\
70-79 \\
\leq 69\end{array}$ & $\begin{array}{c}0 \\
10 \\
21 \\
11 \\
\end{array}$ & $\begin{array}{c}0 \\
23,81 \\
50 \\
27,38 \\
\end{array}$ & $\begin{array}{l}\text { Sangat Baik } \\
\text { Baik } \\
\text { Cukup Baik } \\
\text { Kurang Baik }\end{array}$ \\
\hline \multicolumn{2}{|r|}{ Jumlah } & 42 & 100 & \\
\hline
\end{tabular}

Dari tabel di atas didapat nilai hasil belajar pada Siklus I diperoleh siswa dengan kategori kurang baik sebanyak 11 siswa atau sebanyak 27,58 \%. Sedang siswa dengan kategori cukup baik sebanyak 21 siswa atau $50 \%$, kategori baik sebanyak 10 orang atau 23,81\% dan kategori sangat baik tidak ada.

Dengan demikian dari sudut ketuntasan belajar (yang mendapat nilai di atas KKM secara klasikal atau yang memperoleh nilai hasil belajar lebih dari 69 telah mengalami peningkatan biarpun belum seberapa yaitu dari 8 siswa $(19,05 \%)$ sebelum tindakan setelah Siklus I menjadi 28 siswa $(66,67 \%)$.

1) Nilai Kelompok

Tabel 2. Hasil Kelompok Pada Siklus I

\begin{tabular}{|c|c|c|c|c|c|}
\hline No & Kategori & Kelompok & Jumlah Kelompok & Prosentase $(\%)$ & Ket. \\
\hline 1 & Terbaik & 5 & 1 & 11,1 & \\
\hline 2 & Baik & 6,8 & 2 & 22,2 & \\
\hline 3 & Cukup Baik & $1,2,3,4$ & 4 & 44,5 & \\
\hline 4 & Kurang baik & 7,9 & 2 & 22,2 & \\
\hline \multicolumn{3}{|c|}{ Jumlah } & 9 & 100 & \\
\hline
\end{tabular}

Dari tabel di atas dapat dilihat bahwa kelompok 5 mendapat penghargaan sebagai kelompok terbaik, sedang kelompok 6 dan 8 mendapat penghargaan kelompok baik, dan kelompok 1, 2, 3, dan 4 mendapat penghargaan kelompok cukup baik, serta kelompok 7 dan 9 mendapat penghargaan sebagai kelompok masih kurang baik.

\section{Siklus II}

Kesalahan tindakan yang terjadi pada Siklus I diperbaiki pada Siklus II, yang juga terdiri dari kegiatan perencanaan, tindakan, observasi, dan refleksi, dengan merancang berdasarkan kesalahan, kelemahan, dan kekurangan yang sudah terjadi pada Siklus I.

Tabel 3 Distribusi dan Kategori Nilai Siklus II

\begin{tabular}{|c|c|c|c|c|}
\hline No. & Interval Nilai & Jumlah Siswa & Prosentase (\%) & Kategori \\
\hline $\begin{array}{l}1 . \\
2 . \\
3 . \\
4 .\end{array}$ & $\begin{array}{c}\geq 90 \\
80-89 \\
70-79 \\
\leq 69\end{array}$ & $\begin{array}{c}6 \\
24 \\
9 \\
3 \\
\end{array}$ & $\begin{array}{r}14,29 \\
57,14 \\
21,43 \\
7,14 \\
\end{array}$ & $\begin{array}{l}\text { Sangat Baik } \\
\text { Baik } \\
\text { Cukup Baik } \\
\text { Kurang Baik } \\
\end{array}$ \\
\hline \multicolumn{2}{|r|}{ Jumlah } & 42 & 100 & \\
\hline
\end{tabular}

Dari tabel di atas nilai hasil tes Siklus II, diperoleh siswa dengan kategori kurang baik sebanyak 3 siswa atau sebanyak 7,14\%. Sedang siswa dengan kategori cukup baik sebanyak 9 
siswa atau 21,43 \%, kategori baik sebanyak 24 siswa atau 57,14 \%, dan kategori sangat baik sebanyak 6 siswa atau 14,29\%.

Dengan demikian dari sudut ketuntasan belajar (yang mendapat nilai di atas KKM atau minimal 77) telah mengalami peningkatan yaitu dari 28 siswa $(66,67 \%$ pada Siklus I).menjadi 37 siswa atau $88,09 \%$ (pada Siklus II).

Tabel 4. Hasil Kelompok Pada Siklus II

\begin{tabular}{|c|c|c|c|c|c|}
\hline No. & Kategori & Kelompok & Jumlah Kelompok & Prosentase (\%) & Ket. \\
\hline 1 & Terbaik & $1,2,3,5,8$ & 5 & 55,6 & \\
\hline 2 & Baik & $4,6,7$ & 3 & 33,3 & \\
\hline 3 & Cukup Baik & 9 & 1 & 11,1 & \\
\hline 4 & Kurang baik & 0 & 0 & 0 & \\
\hline \multicolumn{3}{|c|}{ Jumlah } & 9 & 100 & \\
\hline
\end{tabular}

Dari tabel di atas dapat dilihat bahwa kelompok 1,2, 3, 5, dan 8 mendapat penghargaan sebagai kelompok terbaik, sedang kelompok 4, 6, dan 7 mendapat penghargaan kelompok baik, dan kelompok 9 mendapat penghargaan kelompok cukup baik.Pada Siklus II ini tidak ada kelompok yang kinerjanya dalam kategori kurang baik.

\section{Pembahasan Antar Siklus}

1. Hasil Belajar Siswa

a. Nilai Individu

Dari hasil tes sebelum tindakan, Siklus I dan Siklus II dapat dilihat pada tabel berikut :

Tabel 5. Hasil Tes Sebelum Tindakan, Siklus I, dan Siklus II

\begin{tabular}{|c|c|c|c|c|c|c|c|}
\hline \multirow{2}{*}{ No. } & \multirow{2}{*}{ Kategori } & \multicolumn{2}{|c|}{ Sebelum Tindakan } & \multicolumn{2}{|c|}{ SIKLUS I } & \multicolumn{2}{|c|}{ SIKLUS II } \\
\hline & & Jumlah Siswa & $\%$ & Jumlah Siswa & $\%$ & Jumlah Siswa & $\%$ \\
\hline 1. & Sangat baik & 0 & 0 & 0 & 0 & 6 & 14,29 \\
\hline 2. & Baik & 4 & 9,52 & 10 & 23,81 & 24 & 57,14 \\
\hline 3. & Cukup Baik & 20 & 47,62 & 21 & 50 & 9 & 21,43 \\
\hline 4. & Kurang baik & 18 & 42,86 & 11 & 27,38 & 3 & 7,14 \\
\hline & Jumlah & 42 & 100 & 42 & 100 & 42 & 100 \\
\hline
\end{tabular}

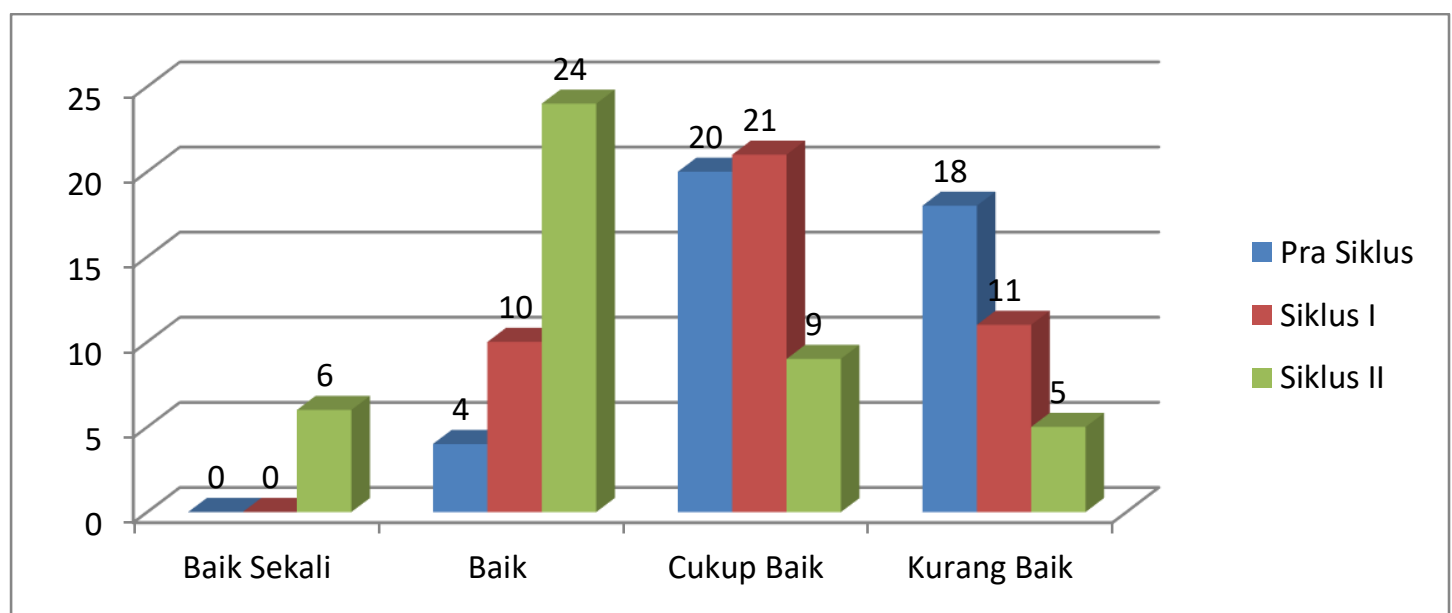

Gambar 2. Grafik tes Sebelum Tindakan, Siklus I dan Siklus II

Secara garis besar hasil belajar individu setelah dilakukan tindakan terjadi peningkatan secara klasikal baik pada Siklus I maupun pada Siklus II. 
Tabel 6. Hasil Kelompok Pada Siklus I dan Siklus II

\begin{tabular}{|c|c|c|c|c|c|}
\hline \multirow{2}{*}{ No. } & \multirow{2}{*}{ Kategori } & \multicolumn{2}{|l|}{ Siklus I } & \multicolumn{2}{|l|}{ Siklus II } \\
\hline & & Jumlah Kelompok & $\%$ & Jumlah Kelompok & $\%$ \\
\hline 1 & Terbaik & 1 & 11,1 & 5 & 55,6 \\
\hline 2 & Baik & 2 & 22,2 & 3 & 33,3 \\
\hline 3 & Cukup Baik & 4 & 44,5 & 1 & 11,1 \\
\hline 4 & Kurang baik & 2 & 22,2 & 0 & 0 \\
\hline & Jumlah & 9 & 100 & 9 & 100 \\
\hline
\end{tabular}

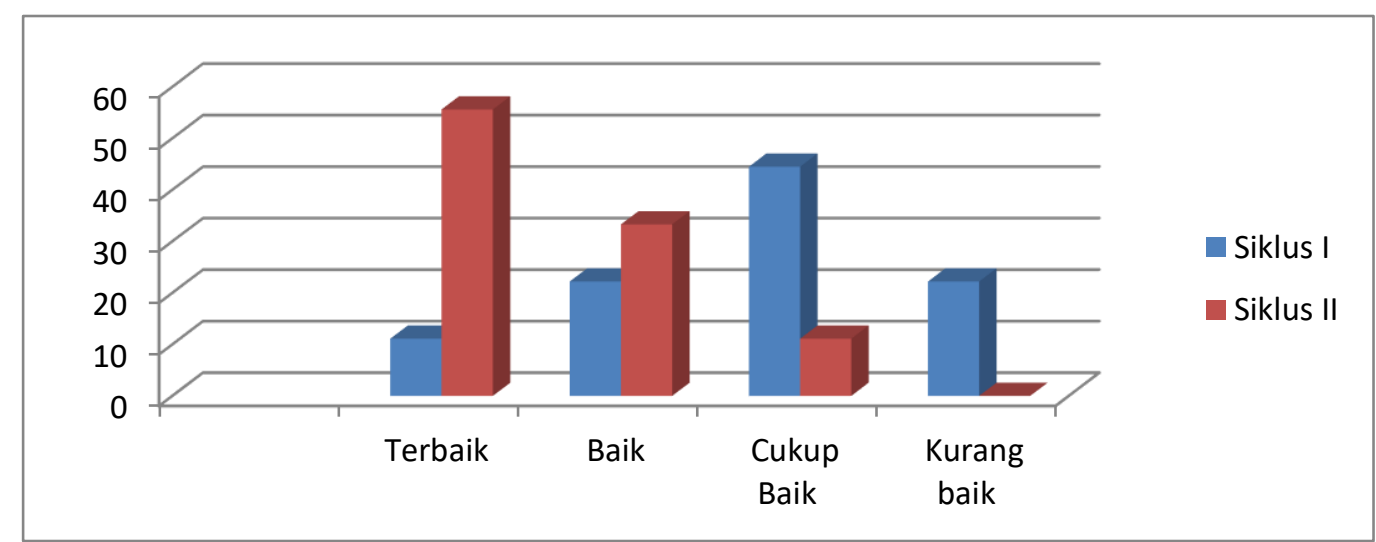

\section{E. Pembahasan Hasil Penelitian}

Berdasarkan permasalahan dalam penelitian, bagaimana aktivitas siswa dalam proses pembelajaran berlangsung dengan menggunakan media ICT dapat dijelaskan bahwa, nilai hasil belajar siswa sebelum pembelajaran (tes awal) dengan menggunakan pendekatan media ICT sangatlah rendah dan belum mencapai standar ketuntasan belajar $(\mathrm{KKM}=77)$. Rata-rata nilai tes awal untuk tes siklus I yang dilakukan sebelum pembelajaran yaitu sebesar 70,93 dengan presentasi siswa yang tuntas adalah sebesar 47,62 \%. Setelah pelaksanaan tindakan pertama melalui pendekatan media ICT pada pokok bahasan dan penerapanya diperoleh gambaran ketuntasan belajar siswa melalui tes akhir tindakan Siklus I, dimana dari 42 siswa yang memperoleh nilai mencapai KKM sejumlah 28 siswa dan 14 siswa lain masih memperolah nilai dibawah 77 secara deskriptif nilai rata-rata hasil belajar siswa pada tindakan Siklus I sebesar 74,62 dengan ketuntasan belajar secara klasikal sebesar 30,95\% sehingga dikategorikan masih rendah.

Pada tindakan Siklus II dari 42 siswa yang memperoleh nilai di atas KKM=77 sejumlah 37 siswa dan 5 siswa yang lain masih memperolah nilai dibawah 77, secara deskriptif nilai ratarata hasil belajar siswa pada tindakan Siklus II sebesar 78,19 dengan ketuntasan belajar secara klasikal sebesar $86,84 \%$ sehingga dikategorikan sangat baik. Berdasarkan hasil analisis nilai rata-rata hasil belajar siswa dengan menggunakan pendekatan media ICT terlihat mengalami peningkatan dari Siklus I, Siklus II sampai dengan post test.

Jika dikaitkan dengan hasil observasi terhadap aktivitas siswa dalam kelompok untuk tindakan Siklus I selama proses belajar mengajar secara deskriptif diperoleh bahwa tingkat aktivitas siswa masih berada pada kategori cukup. Hal ini disebabkan antara lain, siswa belum terlalu paham dengan menerapkan pendekatan media ICT dalam proses pembelajaran, sehingga mengakibatkan aktivitas siswa belum sesuai dengan apa yang diharapkan. Disamping itu pada tindakan Siklus I ini aktivitas guru dalam menerapkan pendekatan media pembelajaran ICT belum mencapai kriteria yang diharapkan.

Setelah melihat hasil obeservasi aktivitas baik terhadap guru maupun terhadap siswa, maka peneliti melakukan perbaikan-perbaikan terhadap rencana pembelajaran dengan melakukan pembelajaran dengan melakukan aspek-aspek baik terhadap cara mengajar guru maupun terhadap aktivitas siswa dalam kelompok selama proses pembelajaran. 
Selanjutnya peneliti kembali melakukan pembelajaran untuk tindakan Siklus II pada hukum bacaan mad lazim mukhoffaf kilmi, mutsaqqol kilmi, mukhaffaf harfi dan mutsaqqal harfi dalam Al-Qur'an. Sebagai upaya perbaikan pada tindakan Siklus I ke Siklus II dengan tetap menerapkan pendekatan pembelajaran ICT. Selain itu pula siswa sudah menyadari dan memahami sasaran yang harus dicapai dalam pembelajaran dengan menggunakan media pembelajaran ICT sehinga sebagian besar siswa aktif dalam proses belajar mengajar.

Rata-rata hasil belajar siswa dalam kelompok dari tes awal, tes tindakan Siklus I dan Siklus II sampai pada tes formatif atau post test mengalami peningkatan, hal ini menunjukkan bahwa peningkatan aktivitas siswa dalam kelompok seiring dengan peningkatan hasil belajar siswa dalam kelompok.

Berdasarkan hasil analisis aktivitas siswa dalam kelompoknya serta hasil belajar siswa dalam pemberian tindakan dengan menggunakan pembelajaran berbasis ICT diperioleh peningkatan baik aktivitas siswa dalam kelompok maupun hasil belajar siswa, sehingga dapat disimpulkan bahwa hipotesa penelitian yang telah diayat al-Qur'ankan sebelumnya dapat diterima

Temuan penelitian ini sejalan hasil penelitian yang dilakukan Nurchaili (2010). Nurchailimengemukakanbahwapemanfaatan TI dalam pembelajaran mampu menjadikan pembelajaran lebih efektif sehingga dapat meningkatkan hasil belajar siswa. Hal ini disebabkanpenggunaanmediapembelajaran berbasis TI memiliki kemampuan menyajikan materi pembelajaran secara nyata dan menarik serta dapat dilakukan berulang-ulang (tetap konsisten) sehingga siswa dapat memahami materi yang disajikan.

Sementara Wardani dan Harwanto (2018) yang meneliti tentang penerapan strategi pembelajaran berbasis ICT terhadap pecapaian hasil belajar, menyatakan penerapan strategi pembelajaran berbasis ICT berpengaruh sangat nyata terhadap pencapaian hasil belajar system computer siswa kelas X SMK kaupaten Gunung Kidul

Studi yang dilakukan oleh Purwanto (2011) menunjukkan bahwa dengan menggunakan pembelajaran interpretatif berbasis ICT diperoleh peningkatan baik aktivitas siswa dalam kelompok maupun hasil belajar siswa, sehingga dapat disimpulkan bahwa pembelajaran interpretatif berb- asis ICT mampu meningkatkan aktivitas maupun hasil belajar siswa pada kompetensi kinematika gerak lurus mata pelajaran Fisika kelas X di MAN Kendal.

Nur (2017) menjelaskan pembelajaran berbasis website banyak menampilkan materimateri yang bervariasi dan para siswa juga dapat berinteraksi melalui online baik dengan materi pembelajaran, teman serta gurunya. Sehingga adanya interaksi multi arah memungkinkan siswa mendapat hasil belajar yang optimal

Faktor ketersediaan sarana prasarana atau fasilitas pendukung ICT merupakan faktor yang dapat mempengaruhi seorang guru memanfaatkan ICT dalam kegiatan pembelajarannya. Selain itu, faktor-faktor seperti faktor sosial yang meliputi dukungan atasan, proporsi pengguna ICT dan kondisi lingkungan kerja, persepsi kemudahan penggunaan ICT sebagai media terintegrasi dan kesesuaian tugas berpengaruh terhadap pemanfaatan ICT dalam proses pembelajaran. Lebih lanjut, pemanfaatan ICT juga berpengaruh terhadap kinerja guru. Dengan ICT, kinerja guru akan semakin baik sehingga guru dapat mencapai efektivitas, efisiensi, produktivitas, kualitas dan kuantitas pekerjaan (Destiana dan Soenarto 2014).

\section{KESIMPULAN}

Berdasarkan hasil penelitian tindakan dan pembahasan yang dilakukan mengenai pembelajaran Qur'an Hadits pada materi hukum bacaan mad lazim mukhaffaf kilmi, mad lazim mutsaqqal kilmi, mad lazim mukhaffaf harfi dan mad lazim mutsaqqal harfi melalui pembelajaran interpretatif berbasis ICT pada siswa kelas IX A MTs NU Banat Kudus dapatlah disimpulkan hal-hal sebagai berikut:

1. Pembelajaran Qur'an Hadits pada materi hukum bacaan mad lazim mukhaffaf kilmi, mad lazim mutsaqqal kilmi, mad lazim mukhaffaf harfi dan mad lazim mutsaqqal harfimeningkat setelah menggunakan pendekatan interpretatif berbasis ICT, dilihat dari: 
a. Peningkatan nilai individu yaitu dari kategori sangat baik sebelum tindakan sebesar $0 \%$, setelah tindakan pada siklus I menjadi $0 \%$ dan setelah siklus II menjadi 14,29\%. Kategori baik dari 4,76 \% menjadi 9,52\% setelah Siklus I, dan 38,01\% setelah siklus II. Kategori cukup baik dari 11,91 \% menjadi 21,43\% setelah Siklus I, dan 35.71\% setelah siklus II, ini berarti terjadi peningkatan hasil belajar siswa dengan ketuntasan hasil belajar siswa secara klasikal mencapai $87,25 \%$.

b. Interaksi siswa dalam kelompok juga mengalami peningkatan setelah dilakukan tindakan dengan menggunakan pendekatan pembelajaran yang berbasis ICT pada siswa,peningkatan nilai kelompok untuk kriteria terbaik $11,1 \%$ pada Siklus I menjadi 55,6 \% padaSiklus II.Kriteria baik pada Siklus I sebesar 22,2 \%, pada Ssiklus II sebesar 33,3 \%, ini berarti interaksi siswa dalam kelompok terjadi peningkatan.

2. Rata-rata hasil belajar siswa dari tes awal, tes tindakan Siklus I dan Siklus II sampai pada tes formatif atau post test mengalami peningkatan, hal ini menunjukkan bahwa peningkatan aktivitas siswa dan interaksi siswa dalam diskusi kelompok seiring dengan peningkatan hasil belajar siswa.

\section{DAFTAR PUSTAKA}

Arikunto, Suharsimi. (2003). Manajemen Penelitian, Jakarta: Bumi Akasara..

Destiana, B., \& Soenarto. (2014). Faktor Determinan Pemanfaatan TIK dan Pengaruhnya Terhadap Kinerja Guru SMK di Kabupaten Gunung Kidul. Jurnal Pendidikan Vokasi,Vol. 4, Nomor 3, 285-299.

Hamalik, Oemar, (2006). Proses Belajar Mengajar. Jakarta: Bumi Aksara.

Made Agustin Permata Wardani, Rufi.i Herwanto. (2020). Penerapan Strategi Pembelajaran Berbasis ICT terhadap Pencapaian Hasil Belajar Sistem Komputer Siswa. Faktor Jurnal Ilmiah Kependidikan, Vol. 7, hal 99 - 106

Nur, M. D. (2017). Pengaruh Strategi Pembelajaran Fisika Berbasis Website Terhadap Hasil Belajar pada Siswa yang Memiliki Self-Regulated Learning (SRL) yang Berbeda. Edcomtech, Volume 2, Nomor 1, 65-76.

Nurchaili. (2010). Pengaruh Media Pembelajaran Berbasis Teknologi Informasi dalam Proses

Pembelajaran Kimia Terhadap Peningkatan Hasil Belajar Siswa. Jurnal Pendidikandan Kebudayaan, Vol. 16, Nomor 6,

Purwanto, Ngalim M. (2007). Psikologi Pendidikan, Bandung : PT. Remaja Rosdakarya.

Purwanto. (2011). Upaya Peningkatan Aktivitas Belajar dan Hasil Belajar Fisika pada Kompetendi Kinematika Gerak Lurus melalui Pembelajaran Interpretatif Berbasis ICT man Kendal. Jurnal Pndidikan MIPA Fakultas Sains dan Teknologi UIN Walisongo Semarang, Vol. 1 No. 2,

Slameto. (2007). Belajar dan Faktor-faktor yang Mempengaruhi, Jakarta: Rineka Cipta.

Usman, Moh Uzer. (2006). Menjadi Guru Profesional. Bandung: PT. Remaja Rosdakarya Bandung. 